Tersedia online di: http://ejournal-balitbang.kkp.go.id/index.php/jra

\title{
PERBANYAKAN TANAMAN HIAS AIR Microsorum pteropus MELALUI KULTUR KANTONG SPORA PADA BERBAGAI SUBSTRAT
}

\author{
Muhamad Yamin**\#, Tutik Kadarini*), dan Lili Sholichah*) \\ *) Balai Riset Budidaya Ikan Hias \\ Jl. Perikanan No. 13, Pancoran Mas, Depok 16436
}

(Naskah diterima: 24 Oktober 2018; Revisi final: 11 November 2019; Disetujui publikasi: 12 November 2019)

\begin{abstract}
ABSTRAK
Produksi massal tanaman hias air pakis jawa Microsorium pteropus melalui pemotongan rhizoma terlihat kurang efisien sedangkan melalui kultur in vitro spora masih sulit dilakukan masyarakat. Salah satu pendekatan baru dalam perbanyakan tanaman $\mathrm{M}$. Pteropus melalui kultur kantong spora telah berhasil dilakukan. Tujuan penelitian adalah untuk menentukan media dalam perbanyakan tanaman $M$. pteropus melalui kultur kantong spora. Potongan daun yang mengandung satu kantong spora diletakkan di atas media tanam, ditutup dengan plastik transparan, dan ditaruh pada lingkungan di luar ruangan (outdoor). Media tanam yang digunakan yaitu: A) cacahan akar pakis; B) serutan kayu; C) cacahan akar pakis + serutan kayu; D) cacahan akar pakis + serutan kayu + kompos; E) pasir gunung berapi (pasir malang); F) abu sekam padi; G) pasir; dan H) tanah. Hasil penelitian menunjukkan bahwa perkembangan sporofit muda (young sporophye) sudah mulai terlihat pada bulan pertama sampai ketiga setelah tanam. Sporofit muda yang berkembang dari kantong spora yang dipelihara pada media pasir, media tanah dan media campuran serutan kayu + akar pakis + kompos menunjukkan rata-rata persentase tanaman hidup yang paling tinggi yaitu $48 \%$ Sebaliknya sporofit muda paling sedikit berkembang pada media akar pakis, media abu sekam padi dan media campuran akar pakis, dan serutan kayu. Berdasarkan hasil tersebut maka media terbaik untuk perbanyakan M. pteropus di luar ruangan melalui kultur kantong spora adalah media tanah dan media campuran akar pakis + serutan kayu + kompos.
\end{abstract}

KATA KUNCl: media tanam; Microsorum pteropus; kantong spora; sporofit muda

ABSTRACT: Propagation of ornamental aquatic plant of Microsorum pteropus through sori culture using different substrates. By: Muhamad Yamin, Tutik Kadarini, and Lili Sholichah

Mass production of Microsorum pteropus through rhizome cuttings has been deemed not efficient while the application of in vitro culture of its spores is still technically difficult to be performed by farmers. A novel approach to mass-produce M. pteropus trough sori culture has been developed and is relatively easy to perform. This study was aimed to determine a suitable propagation media for sori culture of $\mathbf{M}$. pteropus. Small cut fronds containing one sorus were laid on the culture media and covered with a transparent plastic sheet and left on outdoor conditions. The culture media used were: A) fern-root; B) wood shavings; C) fern-root + wood shavings; D) fern-root + wood shavings + compost; E) volcanic sand; F) rice husk ash; $G$ ) sand; and $H$ ) soil. The results showed that young sporophytes developed in the $1^{\text {st }}$ to $3^{\text {rd }}$ month after culture. The young sporophytes developed in the sand, soil and mixture of wood shavings + fern-root + compost medium showed higher numbers of live plants $(48 \%$. In contrast, the lower numbers of live young sporophyte were found in the fern-root, rice husk ash, and mixture of fern-root + wood shavings medium. Based on these results, the best alternative media for propagation of $\mathbf{M}$. pteropus through sori culture on the outdoor conditions are soil media and the mixture of fern roots + wood shavings + compost media.

KEYWORDS: culture medium; Microsorum pteropus; sori; young sporophyte

\section{PENDAHULUAN}

Microsorum pteropus atau pakis Jawa (Java fern) adalah salah satu jenis tanaman hias air yang cukup

\footnotetext{
\# Korespondensi: Balai Riset Budidaya Ikan Hias.

JI. Perikanan No. 13, Pancoran Mas, Depok 16436, Indonesia.

Tel. + 62217520482

E-mail: yaminpaada@gmail.com
}

populer dan banyak dipasarkan di berbagai negara (Johnburom et al., 2016; USDA, 2013). Tanaman ini dapat tumbuh di bawah air dan menjadi favorit untuk aquascaping karena bentuknya yang bagus dan mudah tumbuh dalam kondisi akuarium. M. pteropus memiliki daun berwarna hijau pekat dengan bentuk memanjang dan tumbuh dari rimpang. Selain digunakan untuk 
akuascape, M. pteropus juga dilaporkan dapat berfungsi sebagai antibakteri (Nath et al., 2016) dan bioacumulator untuk cadmium (Lan et al., 2018). Hal ini diduga disebabkan karena tanaman ini memiliki kandungan alkaloid (Djorongaa et al., 2014) yaitu zat yang mempunyai efek berupa pemicu sistem saraf, menaikkan tekanan darah, mengurangi rasa sakit, antimikroba, obat penenang, dan obat penyakit jantung (Simbala, 2008).

Microsorum pteropus, adalah anggota dari ordo Polypodiales dan keluarga Polypodiaceae. Tanaman pakis ini berasal dari dari kawasan Asia Tenggara, Cina, Jepang, Nepal, dan India (USDA, 2013). Namun saat ini tanaman ini sudah tersebar di berbagai negara di Benua Eropa, Amerika Serikat, dan Australia (Johnburom et al., 2016; USDA, 2013). Di alam, M. pteropus menyebar pada daerah dengan ketinggian 0 $800 \mathrm{~m}$ dari permukaan air (MDPL) yang terlindung dari cahaya matahari. M. pteropus biasanya tumbuh di bebatuan berlumpur dekat tepi sungai atau air terjun yang memiliki kelembaban yang relatif tinggi dan intensitas cahaya rendah (Kowalski, 2004; Lansdown, 2011; USDA, 2013). Tanaman M. pteropus terdiri atas beberapa varietas yang berbeda baik dalam ukuran dan bentuk daun. Di akuarium, tanaman ini tumbuh relatif lambat dan membutuhkan cahaya dan $\mathrm{CO}_{2}$ yang relatif rendah.

Perbanyakan M. pteropus dapat dilakukan dengan cara generatif atau vegetatif. Perbanyakan secara generatif adalah perbanyakan tanaman menggunakan spora seperti tanaman pakis lainnya. Organ reproduksi M. pteropus adalah spora yang terdapat dalam sporangia berkelompok membentuk kantong spora atau sori (tunggal: sorus). Kantong spora ini terlihat seperti bintik hitam atau coklat di bagian bawah daun dewasa (frond). Jumlah kantong spora pada tanaman pakis cukup banyak, sebagai gambaran pada satu daun Polypodium scouleri dapat mengandung sampai mendekati 700-an kantong spora (Cody, 2006). Pada kondisi yang memungkinkan, sporangia akan menghasilkan spora yang berkembang menjadi gametofit. Selanjutnya gametofit akan berkembang menjadi zigot, sporofit, dan tanaman pakis muda sampai menjadi pakis dewasa. Selain itu, perbanyakan dapat dilakukan secara vegetatif yaitu dengan menggunakan potongan rimpang (rhizome) dan diletakkan pada media tanam. Namun metode vegetatif ini kurang efisien untuk produksi $M$. pteropus secara massal. Hal ini disebabkan karena dalam satu rimpang hanya menghasilkan beberapa tanaman sementara pertumbuhan tanaman ini relatif lambat.

Untuk mengatasi lambatnya perbanyakan tanaman M. pteropus melalui potongan rimpang, maka salah satu upaya yang dapat dilakukan adalah perbanyakan tanaman melalui spora. Pradissan et al. (2010) melaporkan bahwa perbanyakan M. pteropus melalui spora dengan teknik in vitro telah berhasil dilakukan. Namun sampai saat ini aplikasi perbanyakan M. pteropus melalui spora belum banyak dilakukan masyarakat atau dunia industri karena teknologi ini membutuhkan keterampilan khusus, biaya yang besar, dan peralatan yang mahal. Untuk mengatasi masalah tersebut, maka perlu adanya teknik perbanyakan tanaman M. pteropus melalui spora namun dengan teknik yang lebih sederhana. Salah satu pendekatan yang dapat dilakukan adalah melalui kultur kantong spora.

Seperti perbanyakan tanaman pakis lainnya, perbanyakan M. pteropus melalui kantong spora membutuhkan media dan lingkungan yang cocok dapat berkembang menjadi sporofit muda. Beberapa komponen media tumbuh yang selama ini digunakan dalam aklimatisasi dan kultur sporofit tanaman pakis di antaranya pasir kasar, kerikil, arang, lumut gambut (peat moss), gambut humus (peat humus), serasah daun (leaf mold), lumut (moss), dan pupuk kandang (Thomas \& Garber, 2009; Fernández et al., 2011). Penggunaan pasir dan tanah karena merupakan habitat tumbuh alami tanaman ini di alam (Lansdown, 2011). Penambahan pupuk bertujuan untuk meningkatkan nutrisi di media dan penambahan arang untuk meningkatkan drainase. Tidak jarang juga digunakan media campuran dari bahan-bahan tersebut untuk mendapatkan media yang cukup subur dengan drainase yang baik (Thomas \& Garber, 2009). Sebagai langkah awal untuk mendapatkan media yang sesuai bagi perbanyakan M . pteropus melalui kantong spora dapat dilakukan dengan mencoba beberapa komponen media yang biasa digunakan sebagai media tumbuh tanaman pakis di atas. Penelitian ini bertujuan untuk menentukan media terbaik untuk perbanyakan tanaman M. pteropus melalui kultur kantong spora.

\section{BAHAN DAN METODE}

Kantong spora diperoleh dari daun-daun tua tanaman air pakis Jawa M. pteropus var. Kadaka yang terdapat pada kebun koleksi tanaman hias air Balai Riset Budidaya Ikan Hias (BRBIH), Depok, Jawa Barat, Indonesia (Gambar 1). Penelitian dilakukan di Laboratorium Kultur Tanaman BRBIH. Lokasi kultur kantong spora berada di luar ruangan (out door) berada di bawah atap dan paranet $90 \%$ sehingga kantong spora tidak terkena sinar matahari langsung khususnya dari siang sampai sore hari. Percobaan didesain dalam rancang acak lengkap (RAL) dengan delapan perlakuan media tanam dan dua ulangan. Masing-masing perlakuan media tanam tersebut adalah: A) cacahan akar pakis; B) cacahan serutan kayu; C) cacahan akar pakis + cacahan serutan kayu; D) cacahan akar pakis 


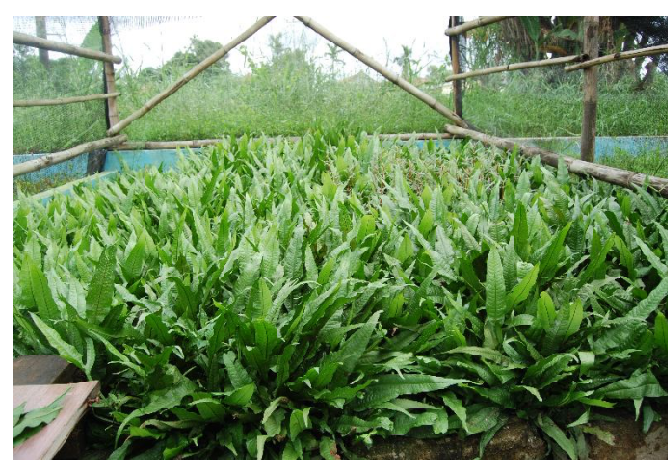

(a)

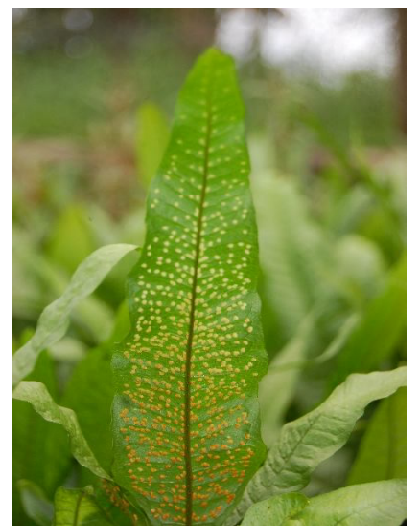

(b)

Gambar 1. Tanaman air pakis Jawa, Microsorum pteropus var. Kadaka; tanaman koleksi M. pteropus di BRBIH (a); daun M. pteropus yang mengandung kantong spora (b).

Figure 1. Aquatic Java fern, Microsorium pteropus var. Kadaka; M. pteropus collection plant at BRBIH (a); a leave of M. pteropus containing sori (b).

+ cacahan serutan kayu + kompos; E) pasir gunung berapi (pasir malang); F) abu sekam padi; G) pasir; dan H) tanah.

Daun-daun dengan kantong spora yang sudah tua (matured) dipilih dari bak pemeliharaan tanaman dan dimasukkan ke dalam kantong plastik hitam. Selanjutnya di laboratorium daun dipotong kecil-kecil (sekitar 0,5 cm x 0,5 cm) sehingga masing-masing potongan berisi satu buah kantong spora utuh. Potongan-potongan daun diletakkan di atas media sesuai perlakuan yang terdapat di baki plastik (lebar $10 \mathrm{~cm}$ x panjang $20 \mathrm{~cm}$ ) dengan posisi kantong spora menghadap ke atas. Kemudian ditambahkan air secukupnya namun tidak menyebabkan potongan daun tergenang air. Selanjutnya wadah ditutupi dengan plastik transparan (plastic wrap) sehingga kedap dan air tidak mudah menguap (Gambar 2). Pada kondisi ini kelembaban dalam wadah dapat bertahan pada $95 \%$ atau lebih. Selanjutnya wadah tersebut diletakkan di lingkungan pemeliharaan yang berada ruangan terbuka (outdoor) di mana pada bagian atas tempat pemeliharaan tersebut terlindungi oleh atap dan paranet $90 \% \mathrm{Hal}$ ini menyebabkan kantong spora tersebut hanya terkena sinar matahari langsung dari pagi sampai siang sebelum pukul 12.00 . Sementara pada siang sampai sore hari wadah akan ternaungi dari sinar matahari langsung. Penelitian dilakukan selama tiga bulan dan penambahan air dilakukan hanya ada media terlihat kekuarangan air. Sampling dilakukan setiap bulan sekali dengan parameter yang diamati adalah jumlah sporofit muda yang berkembang dari kantong spora. Analisis data jumlah sporofit yang berkembang menggunakan ANOVA faktor tunggal (one way anova), dan dilanjutkan Uji Tukey menggunakan software MINITAB.
Kondisi pemeliharaan yang berada di luar ruangan menyebabkan adanya fluktuasi suhu, kelembaban, dan intensitas cahaya harian seperti pada siang dan malam atau akibat perubahan cuaca seperti cerah, mendung atau hujan. Secara umum suhu dan intensitas cahaya mengalami peningkatan dari pagi hingga mencapai puncak pada siang hari dan kemudian menurun sampai sore dan malam hari. Untuk menghindari fluktuasi tersebut maka wadah kultur kantong spora M. pteropus ditutup dengan plastik wrap hingga cukup kedap dan diletakkan pada tempat yang terlindung dari sinar matahari langsung. Pada kondisi ini, kondisi lingkungan di sekitar kantong spora dapat lebih terkontrol. Untuk mendapat gambaran kondisi ruangan pemeliharaan dilakukan pengukuran suhu, kelembaban, dan intensitas cahaya di lokasi pemeliharaan pada siang hari. Gambaran kondisi lingkungan pemeliharaan kantong spora kadaka ditampilkan pada Tabel 1. Dari Tabel 1 terlihat kisaran suhu udara di lingkungan pemeliharaaan adalah $24,0^{\circ} \mathrm{C}-35,9^{\circ} \mathrm{C}$; dengan kadar air berkisar adalah $52 \% 99 \%$ dan intensitas cahaya mencapai 8.500 lux pada siang hari di bawah naungan paranet.

\section{HASIL DAN BAHASAN}

\section{Pembentukan Sporofit}

Persentase sporofit muda yang berkembang dari kantong spora pada berbagai media setelah tiga bulan pemeliharaan ditampilkan pada Gambar 3. Dari Gambar 3 , terlihat bahwa perkembangan sporofit muda dari kantong spora mulai terjadi pada bulan pertama namun dengan persentase yang berbeda antara media. Pada umumnya perkembangan sporofit muda mengalami peningkatan seiring dengan bertambahnya waktu 


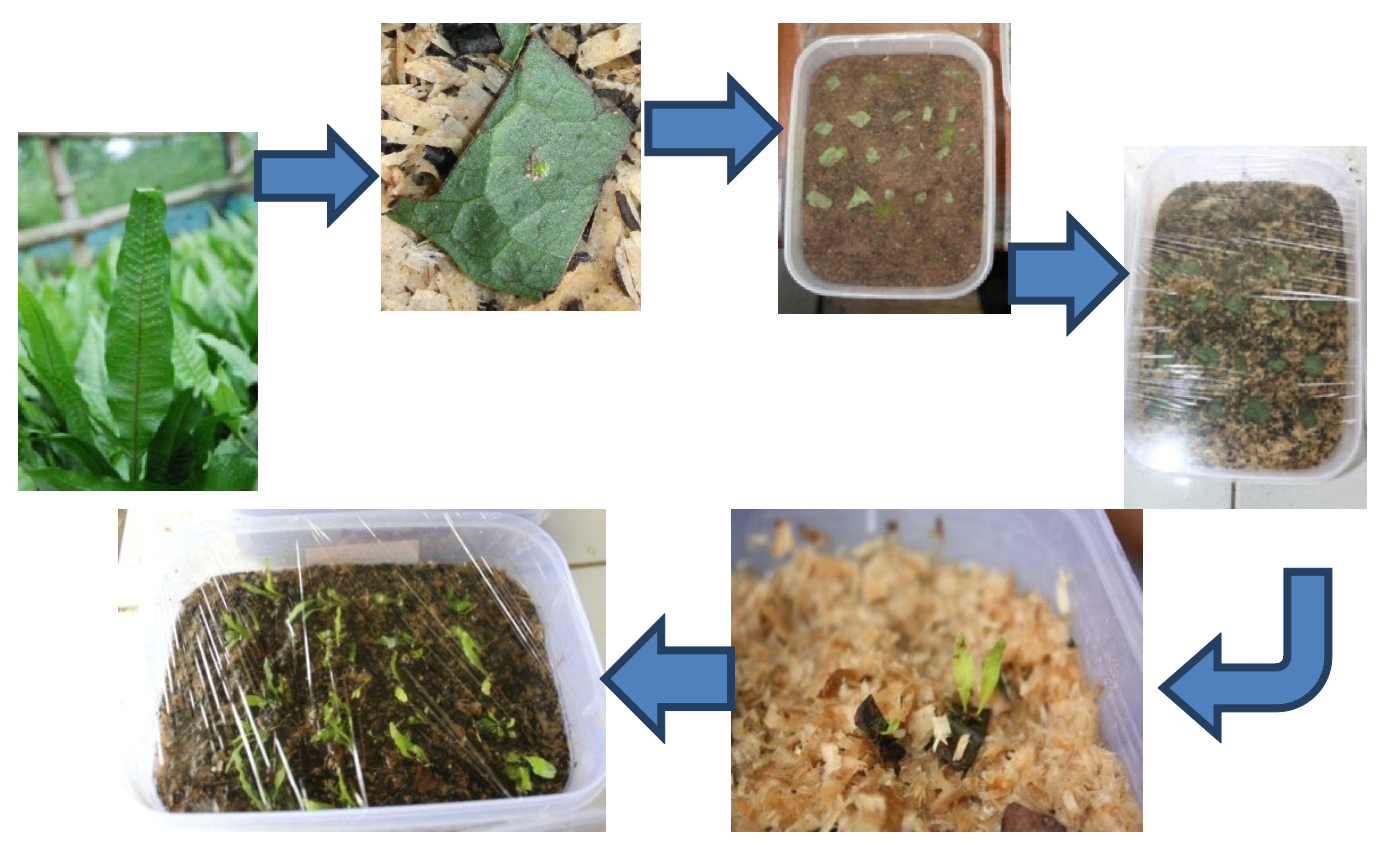

Gambar 2. Metode perbanyakan pakis Jawa M . pteropus var. Kadaka melalui kultur kantong spora.

Figure 2. Propagation method of aquatic Java fern, M. pteropus var. Kadaka, through sori culture.

pemeliharaan (sampai bulan ke-3) khususnya pada media serutan kayu + pakis + pupuk, media tanah, media pasir malang, dan media pasir biasa. Sebaliknya perkembangan sporofit mengalami penurunan yang berarti pada media abu sekam padi di mana pada bulan pertama mencapai $25 \%$ namun terus berkurang pada bulan kedua dan ketiga hingga tinggal tersisa $5 \%$

Pada akhir pengamatan diperoleh bahwa perkembangan sporofit paling besar terdapat pada perlakuan media serutan kayu + pakis + kompos $(48 \%)$ dan media tanah $(48 \%$, disusul media pasir malang $(43 \%$ ), dan pasir biasa (35\%). Sebaliknya paling sedikit sporofit yang berkembang dari perlakuan abu sekam padi $(5 \%$, serutan kayu + akar pakis $(5 \%$, dan akar pakis (8\%). Namun demikian hasil uji lanjut menunjukkan tidak adanya perbedaan yang signifikan $(P>0,05)$ dari masing-masing perlakuan (Gambar 4).
Secara umum, sporofit muda M. pteropus mulai berkembang dari kantong spora setelah satu bulan setelah pemeliharaan. Setidaknya ditemukan satu atau dua sporofit tumbuh di sebagian besar media setelah satu bulan pemeliharaan. Bila dibandingkan dengan kultur spora, perkembangan sporofit muda M. pteropus dari kultur kantong spora terlihat lebih cepat. Goller \& Rybczynski (2007) melaporkan bahwa rata-rata lama waktu pembentuan sporofit muda dari spora dari tiga jenis pakis yang dicobakan adalah germination selama 4-16 minggu, gametophye selama 14-20 minggu, dan sporofit selama 4-14 bulan. Sementara Luna et al. (2016) melaporkan bahwa untuk germination tanaman pakis Anogramma chaerophylla dari spora membutuhkan waktu selama dua minggu.

Persentase terbentuknya sporofit muda dari kantong spora yang terdapat di potongan daun

Tabel 1. Suhu, kadar air, intensitas cahaya di lokasi pemeliharaan

Table 1. Temperature, moisture content, light intensity in culture location

\begin{tabular}{lc}
\hline \multicolumn{1}{c}{ Parameter (Parameters) } & Nilai \\
& Value \\
\hline Suhu/Temperature $\left({ }^{\circ} \mathrm{C}\right)$ & $24.0-35.9$ \\
Kadar air/M oisture content (\%) & $52-99$ \\
Intensitas cahaya/Light intensity (lux) & $2,700-8,500$ \\
\hline
\end{tabular}




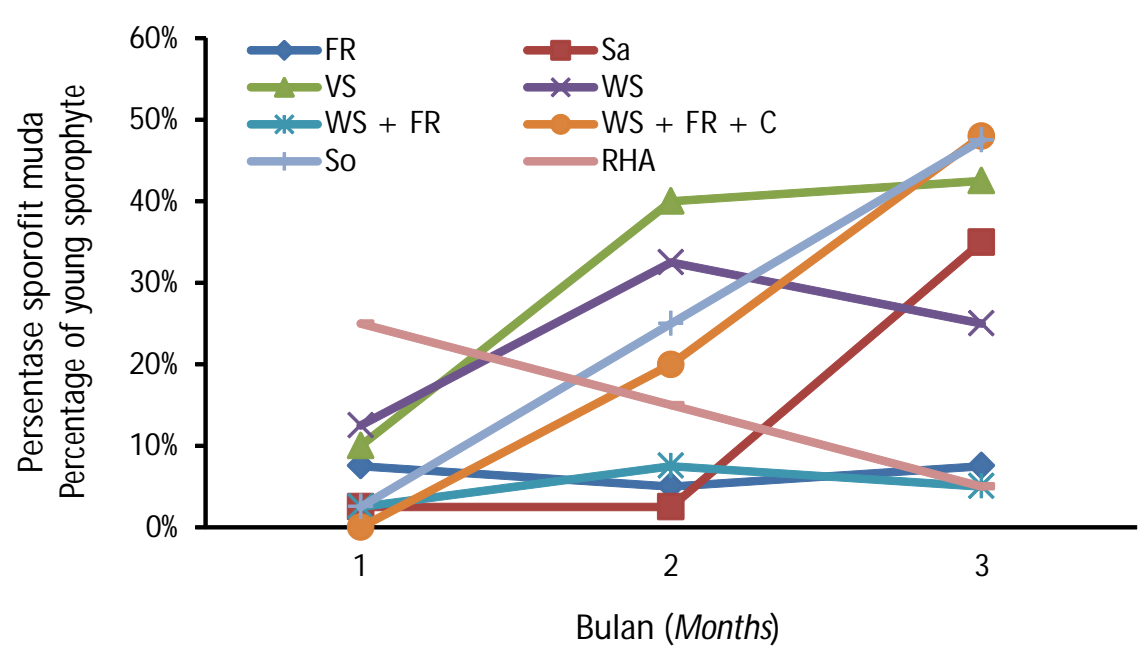

Keterangan (Note): $\quad F R=$ pakis (fern root); $S a=$ pasir biasa (sand); VS= pasir malang (vulcano sand); WS= serutan kayu (wood shaving); $\mathrm{C}=$ kompos (compost); $\mathrm{So}=\operatorname{tanah}($ soil); $\mathrm{RHA}=$ sekam (rice husk ash)

Gambar 3. Kecenderungan perkembangan sporofit muda M. pteropus pada berbagai media tanam selama penelitian.

Figure 3. Growth trend of young sporophyte of $\mathbf{M}$. pteropus in treated media during the experiment.

ditentukan oleh kondisi lingkungan dan media pemeliharaan (Gambar 5). Lebih lanjut Goller \& Rybczyñski (2007) menyatakan bahwa faktor pembatas dalam kultur tanaman pakis adalah intensitas cahaya, lama penyinaran (photoperiod), kelembaban udara, dan media tanam. Hasil uji coba perbanyakan tanaman M. pterpous melalui kultur kantong spora menunjukkan bahwa sporofit yang berkembang dari kantong spora pada kondisi pemeliharaan di luar ruangan baru mencapai $48 \%$ Masih rendahnya persentase sporofit

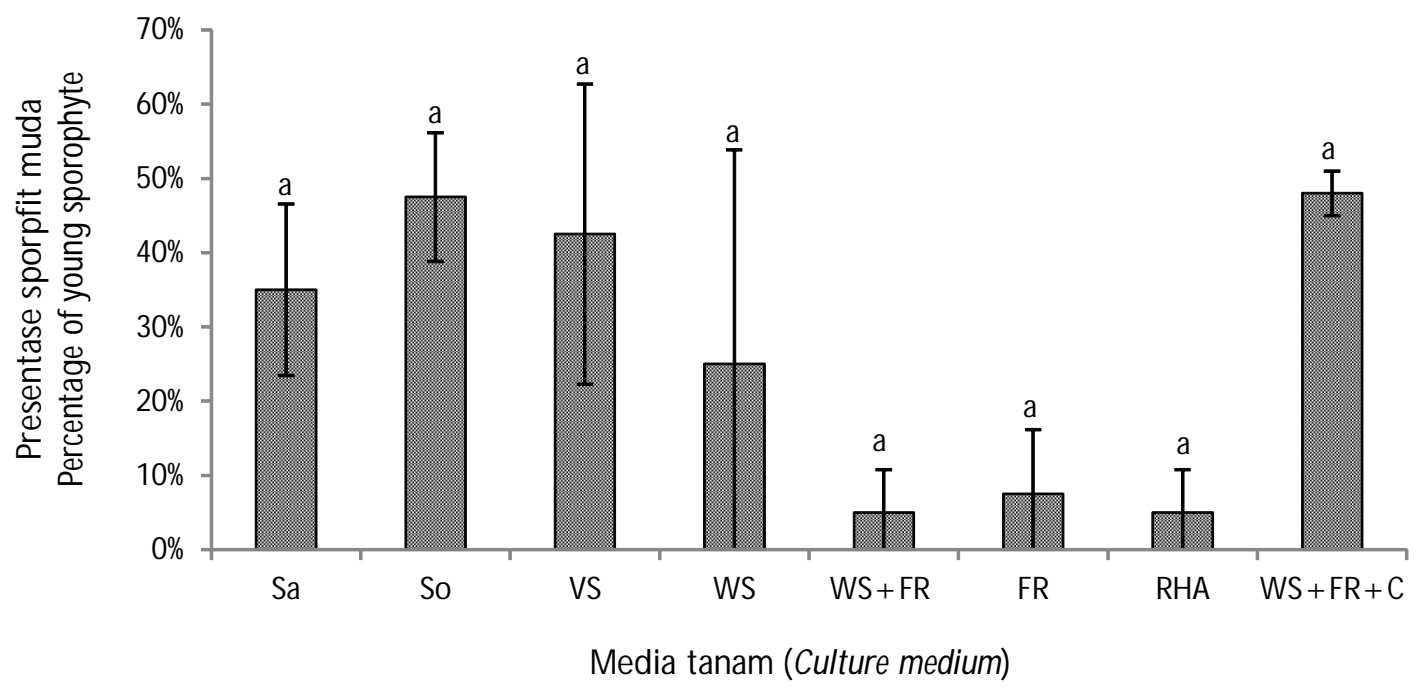

Keterangan (Note): $F R=$ pakis (fern root); $S a=$ pasir biasa (sand); VS= pasir malang (vulcano sand); WS= serutan kayu (wood shaving); $C=$ kompos (compost); So= tanah (soil); RHA= sekam (rice husk ash)

Gambar 4. Persentase sporofit muda M. pteropus yang berkembang pada berbagai media tanam setelah tiga bulan pemeliharaan.

Figure 4. Percentage of young sporophyte of $\mathbf{M}$. pteropus gown in treated media after three months culture. 
yang berkembang dari kantong spora ini diduga dipengaruhi oleh tinggi dan berfluktuasinya intensitas cahaya dan suhu selama pemeliharaan. Setiap tanaman memiliki respons terhadap cahaya yang berbeda di mana ada membutuhkan kondisi cahaya minim, sedang, dan berlebih. Demikian pula tanaman pakis membutuhkan cahaya mulai dari proses perkecambahan sampai tanaman dewasa baik dalam dalam proses metabolisme maupun fotosintesis. Pada penelitian ini, kantong spora terpapar cahaya matahari langsung dari pagi sampai menjelang tengah hari dengan intensitas yang cukup tinggi (sampai dengan
8.500 lux). Intensitas cahaya yang berlebihan dari yang dibutuhkan dapat menjadi faktor pembatas pada tanaman. Bahkan pada cahaya yang kuat dapat merusak enzim akibat foto-oksidasi sehingga menganggu proses metabolisme seperti dalam sintesis protein (Linda, 2007). Adanya pengaruh cahaya pada perkembangan sporofit pakis juga telah dilaporkan pada beberapa studi sebelumnya. Wada (2007) menyatakan bahwa cahaya memiliki peran penting pada perkecambahan (germination) spora pakis dan do rmansi kebanyakan tanaman pakis. Sementara pembentukan sporofit dari spora Pteridium esculentum dan Adiantum

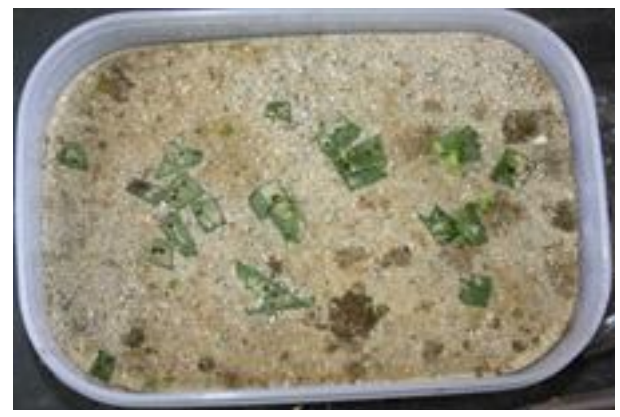

A

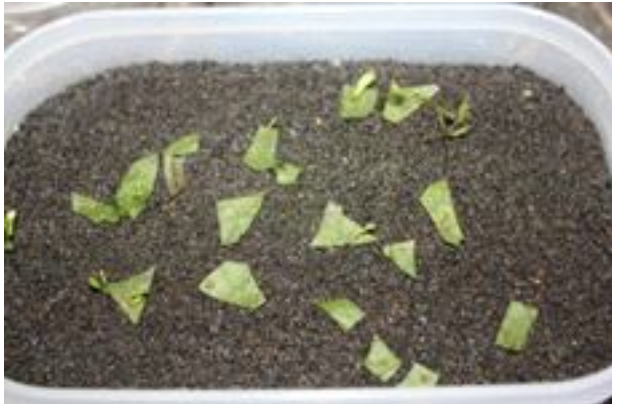

B

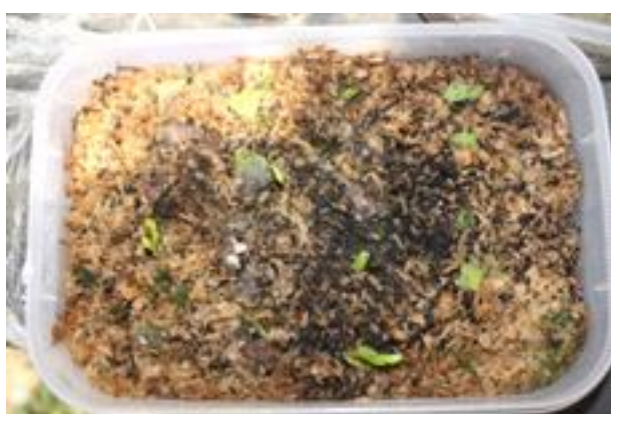

D

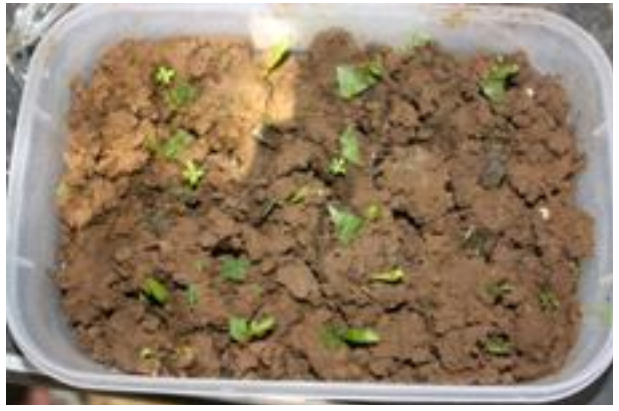

C

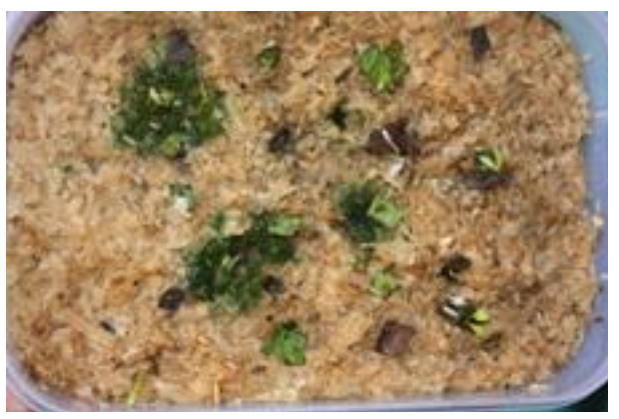

$\mathrm{E}$

Gambar 5. Sporofit muda M. pterupus pada tiga bulan pemeliharaan pada media yang berbeda; $\mathrm{A}=$ media pasir; $\mathrm{B}=$ media pasir gunung berapi; $\mathrm{C}=$ media tanah; $\mathrm{D}=$ media campuran akar pakis + serutan kayu + kompos; $\mathrm{E}=$ media serutan kayu.

Figure 5. Young sporophyte of $\mathbf{M}$. pterupus after three months culture in different media; $A=$ sand medium; $B=$ vulcano sand medium; $C=$ soil medium; $D=$ mixture of fern root + wood shaving + compost medium; $E=$ wood shaving medium. 
reniforme var. Sinense dipengaruhi oleh fase gelap, intensitas cahaya, dan fluktuasi cahaya (Willyams \& Daws, 2014; Hua et al., 2010).

Di samping cahaya, perkembangan sporofit dari kantong spora ini mungkin juga dipengaruhi oleh fluktuasi dan tingginya suhu lingkungan pemeliharaan $\left(24^{\circ} \mathrm{C}-36^{\circ} \mathrm{C}\right)$. Adanya pengaruh suhu pada germinasi tanaman pakis juga telah dilaporkan. Fluktuasi suhu $\left(20^{\circ} \mathrm{C}-30^{\circ} \mathrm{C}\right)$ dilaporkan dapat menghambat germinasi tanaman pakis Tectaria heracleifolia, T. incisa, T. mexicana, dan T. transiens (Pe'rez-Garcý' a et al., 2007). Suhu sendiri berperanan penting dalam mempertahankan viabilitas spora (Whittier, 1990).

Selain kondisi lingkungan, media tanam berperanan penting pada pembentukan sporofit tanaman pakis di mana media berperanan penting dalam memasok air dan nutrisi yang diperlukan untuk germinasi spora dan perkembangan sporofit (Camloh, 1999; Dyer, 1979; Fernández et al., 1997; Higuchi et al., 1987; Khoo \& Thomas, 1980; Mohr, 1963). Dari hasil analisis didapatkan bahwa respons pembentukan sporofit $M$. pteropus terlihat berbeda antar media yang diujikan. Dari semua media yang diujikan, media tanah, dan media campuran akar pakis + serutan kayu + kompos terlihat memberikan hasil yang paling baik. Sebaliknya media abu sekam padi, media akar pakis, dan media campuran serutan kayu dan akar pakis adalah yang paling sedikit menghasilkan pembentukan sporofit muda M. pteropus. Rendahnya sporofit muda yang berkembang pada media akar pakis, media abu sekam padi, dan media campuran serutan kayu dan akar pakis diduga karena media ini kurang baik dalam menyediakan air dan nutrisi bagi sporofit muda. Hal ini terlihat pada permukaan dari ketiga media ini yang terlihat lebih kering dibandingkan media lain. Sebaliknya tingginya sporofit yang berkembang pada media tanah dan media campuran akar pakis + serutan kayu + kompos diduga karena media ini lebih baik dalam menyediakan air untuk menjaga kelembaban kantong spora dan menyediakan nutrisi bagi sporofit muda untuk berkembang. Lebih baiknya perkembangan sporofit pada media tanah diduga karena tanah merupakan habitat asli di mana tanaman ini biasa tumbuh. Menurut Lansdown (2011), bahwa habitat alami tanaman M. pteropus yaitu gundukan tanah di pinggiran sungai kecil atau di batuan basah yang tergenang air atau terkena percikan air yang terlindung dari sinar matahari langsung. Hasil ini sesuai dengan Hua et al. (2010) yang melaporkan bahwa media tanah dan pasir baik dalam sporofit pakis karena dapat menyediakan air untuk pembentukan sporofit untuk tumbuh. Sementara tingginya presentase sporofit muda pada media campuran akar pakis + serutan kayu + kompos diduga karena media ini memiliki kemampuan yang baik dalam menyediakan air dan nutrisi bagi sporofit di samping drainase yang baik. Nampaknya tanaman M. pteropus seperti tanaman pakis pada umumnya menyukai kelembaban udara yang tinggi (Thomas \& Garber, 2009) di mana kelembaban merupakan salah satu faktor penting untuk perkembangan sporofit (Mikula et al., 2015).

\section{KESIMPULAN}

Media terbaik untuk perbanyakan M. pteropus melalui kultur kantong spora adalah media tanah, dan media campuran akar pakis + serutan kayu + kompos. Sebaliknya media akar pakis, media arang sekam padi dan media campuran serutan kayu + akar pakis kurang baik untuk mengembangkan sporofit dari kantong spora. M elalui kultur kantong spora, sporofit muda M. pteropusmulai berkembang setelah satu bulan pemeliharaan.

\section{UCAPAN TERIMA KASIH}

Para penulis mengucapkan terima kasih kepada Bapak Nian untuk membantu selama pelaksanaan penelitian. Penelitian ini dibiayai oleh APBN.

\section{DAFTAR ACUAN}

Camloh, M. (1999). Spore age and sterilization affects germination and early gametophytedev elopment of Platycerium bifurcatum. Am. Fern. J., 89, 124-132.

Cody, M.L. (2006). Plants on islands: Diversity and dynamics on a continental archipelago. California: University of California Press, 259 pp.

Djorongaa, M.I., Pandiangana, D., Kandoua, F.E.F., \& Tangapoa, A.M. (2014). Penapisan alkaloid pada tumbuhan paku dari Halmahera Utara. Jurnal Mipa Unsrat Online, 3(2), 102-107.

Dyer, A.F. (1979). The culture of fern gametophytes for experimental investigation. In Dyer, A.F. (Ed.). The experimental biology of ferns. London: Academic Press.

Fernández, H., Bertrand, A.M., \& Sáchez-Tamés, R. (1997). Gemmation in Osmunda regalis L. gametophyte cultured in vitro. Plant Cell Rep., 16, 358-362.

Fernández, H., Kumar, A., \& Revilla, M.A. (2011). Working with ferns. New York, Dordrecht, Heidelberg, London: Springer.

Goller \& Rybczyñski. (2007). Gametophyte and sporophyte of tree ferns in vitro culture. Acta Societatis Botanicorum Poloniae, 76(3), 193-199.

Higuchi, H., Amaki, W., \& Suzuki, S. (1987). In vitro propagation of Nephrolepis cordifolia. Prsel. Sci. Hortic., 32, 105-113. 
Hua, W., Qun, L.X., Hua, J., \& Qing, C.L. (2010). Effects of light, macronutrients, and sucrose on germination and development of the endangered fern Adiantum reniforme var. sinense (Adiantaceae). Scientia Horticulturae, 125, 417-421.

Johnburom, A., Thenahom, A.A., \& Jaruwattanaphan, T. (2016). A survey of pteridophytes use for aquatic ornamental plants in Thailand. Songklanakarin Journal of Plant Science, 3(II), M01/1-9.

Khoo, S.I. \& Thomas, M.B. (1980). Studies on the germination of fern spores. Plant Propagator, 26(2), 11-15.

Kowalski, E. (2004). Husbandry and breeding of the narrow-striped dwarf siren (Pseudobranchus axanthus). Caudata. Org. Magazine, Issue 1, Autumn 2004.

Lansdown, R.V. (2011). Microsorum pteropus. The IUCN Red List of Threatened species 2011: e.T199682A9116734. http://dx.doi.org/10.2305/ IUCN.UK. 2011-2.RLTS.T199682A9116734.en.

Lan, X.Y., Yang, B., Yan, Y.Y., Li, X.Y., \& Xu, F.L. (2018). Resistance mechanisms and their difference between the root and leaf of Microsorum pteropus: A novel potential aquatic cadmium hyperaccumulator. Science of the Total Environment, 616-617, 480-490.

Linda, R. (2007). Pengaruh cahaya terhadap perkembangan tumbuhan. Jurusan Biologi Fakultas Matematika dan IImu Pengetahuan Alam Universitas Tanjungpura, Pontianak.

Luna, M.L., Yañez, A., Giacosa, J.P R., Gorrer, D., Berrueta, P.C., \& Gabriela, E. (2016). In vitro spore culture and reproductive aspects of the annual fern Anogramma chaerophylla (Pteridaceae). Boletin de la Sociedad Argentina de Botanica, 51(4), 675-682.

MikuLa, A., Tomiczak, K., Makowski, D., Niedzielski, M., \& Rybczyñski, J.J. (2015). The effect of moisture content and temperature on spore aging in Osmunda regalis. Acta Physiologiae Plantarum, 37, 229.
Mohr, H. (1963). The influence of visible radiation on the germination of archegoniate spores and the growth of the fern protonema. Botanical Journal of the Linnean Society, 58, 287-296.

Nath, K., Bhattacharya, M.K., \& Kar, S. (2016). Antibacterial activity of rhizome extracts of four pteridophytes from Southern Assam, North East India. Asian Journal of Phytomedicine and Clinical Research, 4(1), 1-5.

Pe' rez-Garcý' a, B., Mendoza-Ruiza, A., Sa'nchezCoronado, M.E., \& Orozco-Segovia, A. (2007). Effect of light and temperature on germination of spores of four tropical fern species. Actaoecologica, 32, 172-179.

Pradissan, R., Pongchawee, K., \& Pipatcharoenchai, W. (2010). In vitro multiplication of Microsorium pteropus (Blume) Ching, 1933. Inland Fisheries Research and Development Bureau. Department of Fisheries. Ministry of Agriculture and Cooperatives. Thailand. Technical Paper No. 27/2010.

Simbala, H.E.I. (2008). Analisis senyawa alkaloid beberapa jenis tumbuhan obat sebagai bahan aktif fitofarmaka. Jurnal Pacific, 1(1), 489-494.

Thomas, P.A. \& Garber, M.P. (2009). Growing ferns, Bulletin 737, Learning for Live. The University of Georgia and Ft. Valley State University, The United State. Department of Agriculture and counties of the state cooperating. p. 1-14.

USDA. (2013). Weed risk assessment for Leptochilus pteropus (Blume) Fraser-Jenk. (Polypodiaceae)-Java fern. http://www.aphis.usda.gov/plant_health/ plant_pest_info/weeds/downloads/wra/ Leptochilus_pteropus_WRA.pdf.

Wada, M. (2007). The fern as a model system to study photomorphogenesis. Journal of Plant Research, 120, 3-16.

Whittier, P. (1990). Factors affecting the viability of Psilotum spores. American Fern Journal, 80(3), 90-96.

Willyams, D. \& Daws, M.I. (2014). Mass propagation of austral bracken fern (Pteridium esculentum) sporophytes from in vitro gametophyte cultures. South African Journal. 